\title{
From Colonialism to Neoliberalism: Critical Reflections on Philippine Mining in the "Long Twentieth Century"
}

\author{
Alvin A. Camba ${ }^{1}$ \\ Preprint Version. The article can be found at: \\ https://www.sciencedirect.com/science/article/pii/S2214790X15000507
}

\begin{abstract}
Through an analysis of archival data and findings from interviews with industry leaders, I explore the genesis, rise, and fall of the various Philippine mineral regimes of the twentieth century. Specifically, I examine the background of successive and overlapping colonial and neocolonial powers in three eras: late colonial (1901-1941), national developmental (19451964), and state authoritarianism (1965-1985). I also briefly examine the current neoliberal mineral regime (1986-present). I argue that, to date, capitalist enterprises and neocolonial powers have pursued two contradictory paths to extract precious (gold and silver) and base (chromite, iron, copper, nickel, magnesium, and ore) metals in the Philippines. On the one hand, mining companies appropriated expansive land, underpriced labor and inexpensive food to subsidize capital expenditure and mineral operations. The appropriation of basic inputs or what is referred to as "cheap natures" - allowed these companies to reduce their sunken investments and operational costs. But on the other hand, as the sector developed more, it became increasingly difficult to appropriate such "cheap natures." While initially profitable because of successful appropriation of "cheap natures," companies eventually experienced decreasing returns because of the problems this caused.
\end{abstract}

\section{Introduction}

I present a critical historical overview of Philippine mining in light of changes in the global economy since $1900 .^{2}$ Specifically, I examine the genesis, rise, and fall of Philippine mineral regimes, taking into consideration successive and overlapping colonial and neocolonial powers, in three eras: late colonial (1901-1941), national developmental (1945-1964), and state authoritarianism (1965-1985). I conclude by discussing briefly the state of Philippine mining under the current neoliberal mineral regime (1986-present).

To date, considerable research has been carried out on mining in the Philippines, particularly during the country's colonial period and early state history (e.g. Boericke, 1945, Lopez, 1992). In addition, more contemporary analysis that focuses on such themes as local governance (Batongbacal, 2011, Ingelson et al., 2009, Vivoda, 2008), indigenous groups (Holden, 2005,

\footnotetext{
1 Tel: +17039913812; email address: aacamba@gmail.com

${ }^{2}$ With mineral resources valued at almost US $\$ 1$ trillion, the Philippines ranks as the world's fifth-most mineral-rich country, third in terms of gold reserves, fourth in copper, fifth in nickel, and sixth in chromite (Philippine Government, 2010).
} 
Holden \& Ingelson, 2007), local governments (Holden, 2005, La Vina et al., 2012), political economy (Gomez, 2012, Israel 2010, 2011; Orfenio, 2009), development (Rovillos et al., 2003, Rovillos \& Tauli-Corpuz, 2012, Santos \& Zaratan, 1997) and everyday forms of protest (Nem Singh \& Camba, 2015) has been undertaken. Little attention, however, has been paid to broadening understanding of how global-local relations and the long-term trends of historical capitalism in the country have impacted mining.

I argue that, to date, capitalist enterprises and neocolonial powers pursued two contradictory paths to extract precious (gold and silver) and base (chromite, iron, copper, nickel, magnesium, and ore) metals in the Philippines. On the one hand, mining companies needed to appropriate expansive land, underpriced labor and inexpensive food to subsidize capital expenditure and mineral operations. The appropriation of basic inputs - or what is referred to as "cheap natures" - has allowed companies to reduce their sunken investments and operational costs. ${ }^{3}$ The mining sector, therefore, has been able to acquire base and precious metals at very low costs. Profitability has largely depended on the appropriating "cheap natures."

But on the other hand, as the sector developed more, companies found it increasingly difficult to appropriate such "cheap natures." Specifically, the more economic the land, underpaid labor, and low-cost food mining companies "acquired," the more difficult it became for them to maintain this behavior. Put simply, from the US colonial period up until the Marcos authoritarian regime, mining, while initially profitable because of successful appropriation of "cheap natures," eventually experienced decreasing returns because of the problems it caused. When the profitability of these mining companies decreased, a new regime of mineral extraction commenced, during which surplus capital, or "cheap money," for operations was sourced from the world's major financial centers.

The structure of the paper is as follows. First, I outline the theoretical framework of Marxian value relations. Second, I explore the colonial period from 1900 until 1941, when the Philippines was under the Open Door Policy Regime of Great Britain (1901-1929) and subsequently, a Fordist-Keynesian regime in the 1930s. Third, I elaborate on the difficulties

\footnotetext{
3 "Cheap natures," pertain to the basic inputs of food, raw materials, land, and labor that are underpriced vis-à-vis the same inputs from somewhere else (in the developed world or the formal economy protected by laws). The underpriced basic inputs subsidize the economic production process while slowly undermining social reproduction. The low cost inputs contribute to profitability. The rising cost of these inputs increases the cost of production, creates problems of profitability, and facilitates a transition to the next kind of production regime. For some basic references to "cheap natures," see Moore (2014a, 2014b, 2013, 2011, 2010c), Ortiz (2014) and Marley and Fox (2014).
} 
endured by the mineral regime during the postwar period, from 1945 until 1964. Finally, I examine the state-led mineral regime under the Marcos authoritarian government, from 1965 until 1985. In the final section, I briefly discuss the transition toward the neoliberal regime (1986-onward) and reflect on the findings of the paper, against the background of current developments.

I seek to complement the existing literature on Philippine mining by adopting a long-term historical framework, which helps to capture the processes that recur in different eras (Araghi, 2009a, Arrighi, 1994, Braudel, 1981, Bunker, 1985, Bunker \& Ciccantell, 2005, Moore, 2000, 2009, 2011, Wallerstein, 1974). It becomes possible, therefore, to "tease out" the historical genesis of particular processes, to identify patterns of recurrence, and to broaden understanding of the "novelty" of the contemporary period (Arrighi, 1994, Frank, 1978, Wallerstein, 1974). In addition, world-historical frameworks help to situate the dynamics of capital accumulation and sectoral development constitutive of one another. Methodological nationalism that focuses on an economic sector from the state-level perspective gives primacy to endogenous and local forces and often deemphasizes the changes in the global economy (Arrighi, 1994, Bunker, 1985, Wallerstein, 1974). Analysis of the local-global dynamics complements studies carried out at the state level by connecting the dynamics of societies to the evolving dimensions of the global economy (Araghi 2009b, Baran and Sweezy, 1966, Bunker, 1984, Bunker and Ciccantell, 2005, Arrighi 1994, Moore 2010c, 2011, 2014b).

I analyzed government data; material contained in company reports; newspaper articles obtained from the American Chamber of Commerce and Philippine Governor General; and selected US colonial reports. While some of this material covered periods until 1969, to broaden understanding of the dynamics of mining during the postwar and contemporary periods, I conducted field research in Metro Manila, Luzon, and Visayas between 2009 and 2014. Here, I visited several mining sites in Camarines Norte and Nueva Vizcaya, as well as several municipalities in the provinces of Benguet, Ifugao, and Mt Province. Semi-structured interviews were conducted with industry leaders and state actors, as well as local actors, including representatives from peoples' organizations, transnational companies and nongovernmental organizations (NGOs), and inhabitants from mining areas. The material gathered helped to "construct" a picture of the past. 


\section{Theoretical Framework}

\section{1 "Cheap Natures"}

I use the labor theory of value (hereafter, value) in Marxist political economy and Marxist economics, which is premised upon the idea that the "worth" of economic goods and services depends on the amount of socially-necessary labor that was used to produce it (Harvey 2006, 2010, 2013, Moore 2014b). Although the concept is considered futile by mainstream neoliberal economists, ${ }^{4}$ I consider value as the dead or used labor that is congealed in commodities made from the economic production process (Harvey, 2013, Moore, 2012, Moore, 2014b). For Marx (1977), commodities are products of a division of labor, varying specializations among and technologies available within a population, varying levels of technical production, and the social interdependencies and class relations in a society. Marx further argued that because economies are tied to one another internationally, societies are interconnected and become a part of the interdependencies and class relations of even bigger economies (Brenner, 2006, Burkett, 1999, O'Connor, 1998). In terms of value, therefore, it is not that labor-intensive economies are more profitable than capital-intensive ones, but rather that capital-intensive sectors also depend on labor-intensive ones. Market volatility, supply and demand, and other concepts used to explain the rise and fall of prices are bound to, and cannot be separated from, value (Harvey, 2006).

Such a notion of value has been criticized for having a nature-blind perspective and its inadequate treatment of informal labor, unpaid work, or work outside of the formal economy (Araghi 2003, 2009b, 2010; Burkett, 1999, 2003; Moore, 2010c, 2011, 2012, 2014a; Peet and Watts, 2004). These types of work not only make up the entire economy of a state but also become crucial in the reproduction of conditions needed for formal labor to continue producing (Araghi 2003, 2010, Peluso, 1992). The so-called reproduction process, as the literature on feminism points out, has crucially depended on women's household labor and underpriced domestic labor in the developed and developing worlds: cooking dinner, cleaning the house, and paying the bills. Put simply, this is the kind of "small" work that is not fully

\footnotetext{
4 Conventional explanations from the neoclassical economic and governance literature focus on technological innovation, competitive advantage, the efficiency of firms, and the robustness of institutions to explain profitability and capital accumulation. The problems with these explanations have been explored and elaborated on in some other works. I focus on two points. First, these explanations shy away from analyzing the process of production and producing goods and services. The explanations focus on external institutions and agencies that could condition profit, but they do not take stock of the division of labor and the social production that makes up a society. Second, these explanations are abstracted generalizations of particular conditions for profitability, but they do not analyze the interrelations that explain why some goods and services are worth more than others.
} 
encompassed by the market and is treated as being "outside the formal economy" but when aggregated altogether becomes the key reason for production to renew once again (Federici, 2012). However, as eco-Marxists have pointed out, value needs to consider the use of nature's unpaid work in the production and reproduction processes (Burkett, 1999, 2003, Peluso, 1992, Moore 2010, 2014a).

To treat nature's unpaid work fairly in economic production and social reproduction, I use a value relations approach from the research paradigm of world-ecology (Marley \& Fox, 2014, Moore 2009, 2010a, 2012, 2014a, Ortiz, 2014), which is premised upon two important points. The first is that both production and reproduction have "the wealth of uncommodified human and extra-human natures in service to advancing labor productivity within commodity production" (Moore, 2014b: 1). As such, social relations, class inequalities, technological innovation, and unpaid household work have come to depend in part on the appropriation of - taking without fully paying for - nature: the fertility of the soil for food, the freshness of the air, the expansiveness of the land, and the power of resources. In the mining sector, this would include, for example, the use of free lumber to build mining facilities, and the use of rivers as dumpsites. The fertility of the soil and the existence of food at costs below the market rate constitute basic inputs that allow for, and cheapen the cost of, production and reproduction (Araghi, 2009, 2009b, Moore 2014b). These "natures" are appropriated informally and exist outside of the market economy; as a result, the cost for capitalist enterprises lessens (Burkett 2003, Mitchell, 2013, Moore, 2008, 2010b). For example, with the availability of inexpensive food in certain areas, companies can offer lower salaries and stave off wage increases. As Moore (2014b) argues, capital must "deliver labor, food, energy, and raw materials (the 'Four Cheaps') faster than accumulating a mass of surplus capital derived from the exploitation of labor-power" (p. 8). Put simply, the exploitation of workers in capitalized processes depends on the capacity of capitalism to acquire unpaid work from somewhere else to perpetuate exploitative processes (Araghi, 2009a, Burkett, 1999, Foster 1998, 1999, Moore, 2012, 2014a).

Second, the appropriation of unpaid work produces new kinds of natures (Araghi, 2010, Moore, 2014b). High demand for underpriced lumber can cause deforestation and deteriorate the fertility of soil. The use of workers without provisioning medical insurance increases incidences of untreated disease, which can be passed on from one generation of workers to another (Foster, 1999, 2012). Value relations, therefore, take into account that appropriation changes the conditions for future appropriation of nature, as well as what capitalism and 
historical processes create over time (Moore 2012, 2011). Historicized "natures," then, are left behind and must be dealt with in future phases of accumulation. In short, although the increasing windfalls of "cheap natures" bring down the wage bill of formal labor contracts and investment cost for capitalist enterprises, increasing and continuous appropriation may also contract profitability and exhaust the conditions of accumulation.

\section{2 "Cheap" Money}

Finance capital includes any economic resource that is transformed into derivatives, securities, and asset-cash swaps (Arrighi, 1994, Brenner 2006, Krippner 2005, 2011). A finance-based global economy is characterized by: (1) the use of financial instruments to generate profits; and (2) the shrinking contribution of economic production in the world's overall economic activities (Arrighi, 1994, Moore, 2012). The role of finance capital has been heavily debated in the context of falling profits. For Marx (1973), finance capital, along with industrial capital, determines the structure of companies and their activities. Although there is some debate today over whether financialization is a new phase of accumulation, there is a common understanding that it takes place when there is a need to move into newer, more profitable, ventures (Arrighi, 1994, Brenner 2003, Harvey, 2006). Some important sources of finance capital include stock market trading, investment portfolios, and low-interest loans from states (Krippner, 2005, 2011).

Money becomes "cheap" when existing investments become less costly than the basic inputs or "cheap natures" acquired that are necessary in production (Moore 2014b). The rising costs of food, labor, and resources in particular areas are and can be temporarily assuaged by money to expand the frontiers of accumulation: to hire cheaper workers, explore new mineralized areas, and purchase cheaper food from indentured agriculture. "Cheap money,"

in this sense, is a relational moment between the rising cost of inputs and the faltering profit levels of mining companies (Moore 2014a, 2014b), as well as the increasing availability of surplus capital from capitalists from other sectors. Most pivotally, "cheap money" can expand profitability at a particular temporal moment when everything else is expensive in relation to the present and the forecasted rate of profit. Even with the more difficult conditions of appropriating "cheap natures," the accessibility of liquid capital from financial instruments allows for spurts of mineral exploration and extractive activities. These activities may temporarily assuage falling profits by increasing profits in the short term, but may further 
exhaust supplies of manpower and "natures," consequently decreasing profits over the long term.

\section{Colonial Political Economy (1901-1941)}

Toward the end of the 19th century, the United States began to colonize the Philippines. The historical genesis of the sector can be traced to US colonial rule and the concurrent expansion of capital. ${ }^{5}$ At this time, the Philippines had shifted away from Great Britain's informal empire and was incorporated into a US regime of monopolistic capitalism, under which the colony's mining sector began attracting strong interest from American political and economic elites. In 1901, the Taft Commission, a body of state officials responsible for assessing the viability of the Philippines for investments, reported to US President McKinley that "gold mines grow more favorable as the operations of prospectors are extended" because "modern gold-mining machinery has never been used in the Philippines" (Report of the Taft Commission 1901, 51). As early as 1903, the Governor General of the Philippines moved to reestablish "throughout the archipelago active mining operations [which] have begun at several different points with good hope of success" in "Mambulao and Paracle, in Ambos Camarines, and upon several gold-mining claims in the province of Benguet" (Governor General, 1903: 33).

By 1906, there were over 500 mining applicants, which provided a gateway for Western capital and empowered them to enter and move across the-mostly unfettered lands of the country, as well as territories occupied by the relatively insulated indigenous groups in the Northern Mountains and Moros in Mindanao. From here, the mining industry grew, on the back of successful appropriation of low-cost land and lumber, which supported the early exploratory missions and property acquisition of mineral proprietors. The "unpaid work" from, and power of, lumber, water, and the land provided the conditions for extracting precious and base metals from prospective mines. Marx (1973) argued that soil fertility can act as fix capital (p. 748). Cheap lumber and the soil's fecundity can act in the same way:

In any cold climate this prospector would have been frozen out long ago and left the country in despair but here, in the midst of perpetual springtime for the region in between 5 and 6 thousand feet elevation-he turns to the soil for support, building a small cabin of readily accessible materials, planting a garden around it, and raising chickens and hogs to supply himself with food, In many ways, the country is ideal for

\footnotetext{
5 There were small but complex mining structures in the Philippines even before Spanish colonization. The earliest export data, however, date back to the 19th century, when the Philippines exported US $\$ 2,426,655$ in precious and base metals in a span of 100 years (American Chamber of Commerce, 1929). The Spanish finally recognized the mineral sector in the late-1800s, as demonstrated by the implementation of the 1874 mining law. Although some companies were established, because of the lack of interest from major capitalist classes in the Philippines, largely because of the Spanish regime's limited support, mining never really held a significant role.
} 
mining development...There is ample timber for all mining construction. [Census, 1905: 83]

Figure 1: Principal mining districts during the colonial period

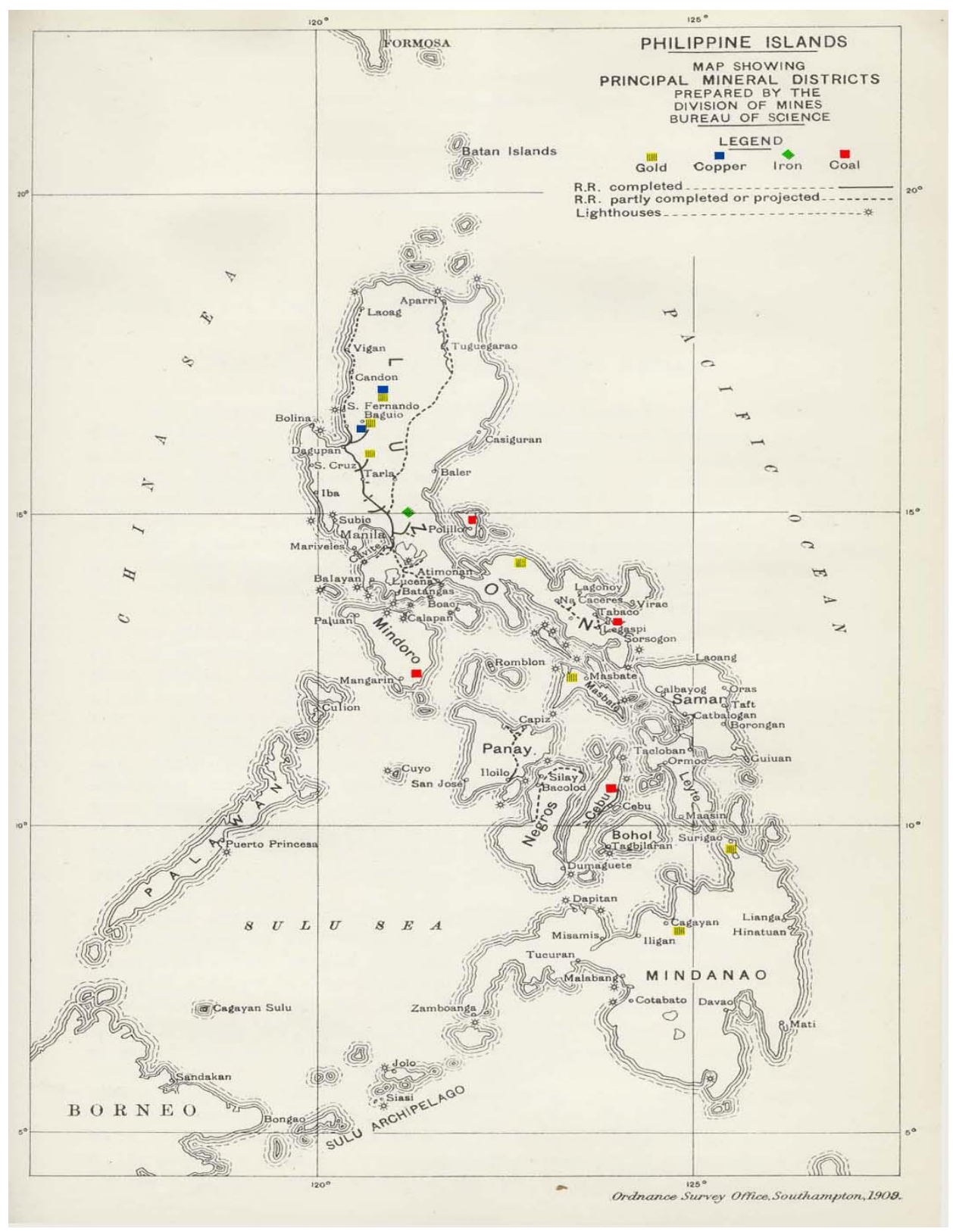

Source: Diplomatic \& Consular Reports, 1909

As seen in Figure 1, a number of mineralized areas had been identified in the early twentieth century. The US colonial government freely appropriated land to build and support mineral infrastructures. Resources in the form of wood and water were vast and unblemished. Wood was appropriated for exports to the US market, and provided the foundation for mine 
infrastructure. Food prices were kept low through fixed prices set by plantations, which used indentured labor. ${ }^{6}$ The soil's fecundity provided energy and rendered life to raise food and produced the spaces needed to breed work animals, which helped early prospectors survive in the vast and isolated areas of the Philippines. Early estimates of forest reserves by the last Spanish Governor General suggest that $70 \%$ of the country, or approximately 80,000 square miles, was covered by forest, including woodlands (Census, 1905). Mining infrastructure "used" free and accessible water bodies, such as the Abra River, "a large, fast-flowing stream" that "offers more power than will ever be required" (Census, 1905: 83) and which supplied fish for workers. Although labor in the Philippines costs US $\$ 0.25-$ US $\$ 0.40$ per month (Census, 1905), far cheaper than labor in the West, mining companies paid their workers at even lower rates because of the "subsidy" provided by free wood and accessible fish. ${ }^{7}$ "Cheap natures," therefore, were the materials obtained freely by early prospectors to expand infrastructure, which helped to "subsidize" the full cost of mine infrastructure in Northern and Southern Luzon (Census, 1905: 84).

The Jones Law, implemented in 1916, formalized the power of the United States to allow foreign corporations to own more land and extract resources in the Philippines. The Governor General stated at the time that the "year has been marked by much interest in legislation concerning mining with taxes placed on the gross output of mines" (Governor General, 1916: 78). Average annual investment input in the Philippine mining sector was US\$1-US\$2 million up until the 1930s. From 1900 to the early 1930s, the US colonial government extracted gold worth US\$27,093,300 (American Chamber of Commerce, 1929: 9), and during this time, the United States extracted gold used by their mints. The Philippines became second to South Dakota in world gold production because of US inputs (Keeler 1937, 19). An editor from the American Chamber of Commerce remarked at the time that in "getting the Philippines, the United States paid Spain US[\$]20,000,000. Here it is, with interest, from some of the mineral lands of the public domain which the payment covered. This gold went to U.S. mints" (American Chamber of Commerce, 1929: 9). Large-scale production of base metals, such as iron in the provinces of Calambayanga, Angat District, Bulacan province, and Surigao, copper at the old Mancayan properties, and coal on Batan Island, Gotas-Butong, Cebu, and other areas, did not begin until the 1920s (Warren, 1921: 15). ${ }^{8}$ The mining industry in 1921 exported precious and base metals valued at US\$3,217,843.33 (American Chamber of

\footnotetext{
${ }^{6}$ Indentured laborers are peasants paid in "kind" or sometimes in cash. Peasants had the right to use the land owned by the bigger landholders in exchange for their labor (Census, 1905).

7 Cents pertain to the American unit of currency as equally one one-hundredth of a United States dollar.

${ }^{8}$ Quite similarly, Latin America also experienced an increase in base-metal demand after World War I, mainly extracted for the electrification of Europe and the United States.
} 
Commerce, 1929, Warren, 1921: 16). ${ }^{9}$ Warren Smith, the-then acting head of the US colonial government's Division of Mines in the Philippines, wrote in 1921 that the "use of gold as a basis for money practically throughout the world, and its universal appeal to mankind as treasure, plays a tremendous role in our economic system, so that a country today finds it imperative to have a gold supply" (Warren 1921: 13). Warren was referring to the United States' addiction to gold in the early 1900s, fuelled by the American Gold Standard Act, which allowed US government checks, greenbacks, and silver certificates to be redeemed in gold. Gold supplies were important through the late $19^{\text {th }}$ century and until the early $20^{\text {th }}$ century. In the $19^{\text {th }}$ century, the rising supply of gold institutionalized the gold standard vis-à-vis the silver (Brown, 1929, Cassel, 1966). When gold became the international standard during the predominance of the British Sterling, the access of the US Government to the abundant supply of gold from Philippine mines allowed American businesses to convert gold into bonds and greenbacks in the London market (Brown, 1929, Gallarotti, 1995). Gold, acting as the payment for international imbalances, facilitated international monetary activities and loans to US corporations, expanding the credit for further investments (De Cecco, 1984, Gallarotti, 1995). While most industrial countries adhered to the gold standard, not everyone had access to mines, and by implication, the higher quantity of gold in the hands of Americans enabled US businesses to borrow capital from Europe (Brown, 1929). In short, the United States needed to acquire gold to borrow foreign capital during the tumultuous early $20^{\text {th }}$ century.

While initially beneficial for international transactions and international trade, adherence to the gold standard induced deflationary pressures to countries because their capacity to acquire gold often outran the growth of their economies. ${ }^{10}$ The stock market crash in 1929 and Great Depression pressured countries to abandon the gold standard in 1931 (Brown, 1929).. The Gold Standard Act of 1934, passed after the New Deal, disallowed domestic convertibility from gold to the US dollar. The US government started purchasing gold from private owners in exchange for credit and loans, injecting more currency in the economy to induce economic production and employment (Gustav, 1966). Otherwise known as the Fordist-Keynesian regime of expanded credit for state corporations and US businesses, the more competitive US exports to the depressed European economies shielded the US economy from greater deflationary pressures (Gustav, 1995). The expanded credit helped create the competitiveness of the dollar in the world economy (Brenner, 2006, Gustav, 1995, Panitch

\footnotetext{
${ }^{9}$ The Philippine Coinage Act of 1903 set the Philippine pesos's rate to exactly half the value of the U.S. dollar.

10 Deflation induced investors to hold onto their capital instead of investing, resulting in the contraction of economic production.
} 
and Gindin 2012). Gold flew out of the Philippines, leading to a more competitive dollar and strengthening the trading power of the United States vis-à-vis other European powers.

Changes in the world economy brought about by the Great Depression altered the colonial mining regime in the Philippines significantly. Money moved from the financial centers of the West into potential mining lands in the Philippines (Gowen, 1937). Known as the "Philippine Mining Boom," the activities of brokers in stock exchanges were enormous. The opportunity for profit was vast, and thousands of investors competed for favored shares through the endless telephone and telegraph communications, increasing the flow of foreign funds and bidding the shares upward (Gowen, 1937). Derivatives, financial instruments, and stock prices indeed went up; new mining companies were created; and, old companies expanded. Speculation also became rampant, transforming promising investments into sizable ventures in a short period (American Chamber of Commerce, 1936f, 1937a, 1937b).

Mine production indeed increased. Exports rose; new fields were located and explored; and capital moved across frontiers. ${ }^{11}$ Propelled by investment which rose from US\$7,337,202 in 1935 and US\$8,095,392.5 in 1933, gold exports vastly increased in 1936, with 15 huge gold mines producing output at a combined value of US $\$ 9,828,285.5$ (Gowen, 1937, United Press, 1937). In 1940, the highest output achieved was reached at US\$39,229,352 (Lim, 1951:417). The gold boom in 1933 resulted in prospectors swarming "all over the hills and new companies springing up like mushroom growths on every hand" (Keeler, 1936a). Indeed, investment and speculation was "organizing" nature in the Philippines, reminiscent of "California and Alaska, with the mounting price of gold" (Keeler, 1936a) New mining structures were created: the big wedge by the Atok Gold Mining Company, a new bill by East Mindanao Mining Company, and several new contracts in the chromite industry (Keeler, 1936a). Benguet also increased its production from US $\$ 500,000$ to US $\$ 1,000,000$; and Marsman and Company acquired new contracts and constructed new mills in Itugon, Suyoc, and Camarines Sur (American Chamber of Commerce, 1936f).

The high returns of finance and investment in gold were, however, not enough. With the tenuous political situation in Europe and East-Southeast Asia, mining companies capitalized on the rising demand for base metals for industrial and military production (American

\footnotetext{
${ }^{11}$ Gold was still significant because of its quasi-convertible standard for international transactions, which meant that it could be used in international transactions. The quasi-convertibility, however, was still very important because it allowed the United States to print more money, and spend its way out the Great Depression, while maintaining the importance of gold in international terms (Panitch \& Gindin, 2012).
} 
Chamber of Commerce, 1939a, 1939b). Due to an influx of surplus capital, the mining industry as a whole became a major part of the colonial political economy through the explosive growth of the mining regime, which expanded from precious to base metals (United Press, 1937: 29). This resulted in new waves of mineral frontiers and mining areas (American Chamber of Commerce, 1936b). The Keynesian-Fordist regime in the United States increased the demand for base metals (American Chamber of Commerce, 1937b): new supplies of copper, lead, zinc, and tin, for the surging production of domestic enterprises funded by state credit. As Bolivia and Malaysia's mining industries waned (United Press, 1937: 32), the Philippine mining industry boomed, exporting a total of US $\$ 1,032,750$ and extracting minerals from 19 large mining structures by 1936, including that of Antamok Goldfields and the United Paracle mines (American Chamber of Commerce, 1937a). There were as many as 500 companies in possession of over 1000 mines of various sizes (American Chamber of Commerce, 1937b), employing a total of 50,000-75,000 laborers and hundreds of thousands of other people in auxiliary work. Marsman companies, Tambis Placer, Salacot and Nielson expanded their operations, opening new mines (Keeler, 1937: 19). Base metal exports in 1933 were valued at US $\$ 21,547.5$, but at its peak in 1940 , they were worth US\$6,574,253 (American Chamber of Commerce, 1936a). The speculation of potential mineral lands continued across the country: prospectors dispersed, and communities were displaced (American Chamber of Commerce, 1936a, 1936b, 1937b). Purchasing land at low costs and selling high to international investors was a common practice; it became alarming enough that the Chamber of Mines contemplated placing limitations on short-term investments (American Chamber of Commerce, 1936a, 1937a, Keeler, 1937).

The colonial mineral regime ended because of the increasing cost of appropriating "cheap natures."12 The massive surge of "cheap money" in the 1930s sparked a flurry of mineral exploration activities which had significant environmental impacts, and perpetuated social stratification and political asymmetry (Flynn, 1937, Gallego, 1939, Kerkvliet, 1977). It eventually became challenging to expand into new mineral frontiers because of the political conditions of the US colonial regime and the social conditions of Philippine society. The Commonwealth status of the Philippines brought more political obstacles: the Philippine Bureau of Mines replaced the US Division of Mines and Bureau of Science (responsible for mineral governance); environmental and labor protection laws were put in place; and Philippine nationals were given formal powers in the bureaucracy. Although there were

\footnotetext{
12 Some in the World-Systems tradition argued that World War II was a challenge for supremacy in the capitalist world-system (Arrighi, 1993, Wallerstein, 1974). The Philippines and most mining companies were severely affected during the war.
} 
accompanying provisions of liberalization in the Commonwealth's Philippine Mining Act of 1936 (American Chamber of Commerce, 1936c, 1936d), citizens began to play important roles in economic and political institutions. In addition, the increasing capitalization of the economy induced increased in labor from a monthly wage of 25 to 40 cents in 1905 to 75 to $\$ 1.50$ in 1939 (Census, 1905, 1939). Food prices increased because plantations wanted to produce more cash crops instead of rice to capitalize on the rising prices in the world economy (Kerkvliet, 1977, 1986). Numerous incidents of contamination from mineral tailings, soil erosion and denudation were reported in many mining areas, sparking strikes and rallies by mining workers and communities in Benguet, Antamok, Paracle, and Eastern Mindanao (American Chamber of Commerce, 1936e, 1937b, Keeler, 1936). Eventually, the cost of labor rose in the Philippines. A mining industry with increasing capital and technical requirements meant that skilled labor and mineral knowledge began to have more "power" (Flynn, 1937: 20, Gallego, 1939, Kerkvliet, 1977, Salonga 2000). Numerous rallies and strikes occurred in Benguet and Lepanto, and at the Marsman Corporation, increasing the cost of labor for companies (American Chamber of commerce 1937a, 1939a, 1939b, Brimo, 1953, 1961). It was no longer straightforward to acquire potential mineral lands and appropriate surrounding areas to support mining activities.

The mining industry's expansion throughout the years affected agriculture and other resource export sectors. The overall incorporation of the Philippines into the colonial political economy meant that the growing population and expanding agricultural frontiers had to compete for land, resources and space. Agricultural lands competed with the capitalized mineral and lumber frontiers, leading to less remuneration and more work for peasants (Gallego, 1939, Kerkvliet, 1977, 1986). The growing food supply problem was exacerbated by a reliance on fertilizer that harmed the reproduction of the soil's fertility (American Chamber of Commerce, 1939a, Gallego, 1939). The situation ultimately became untenable and, indeed, this was one of the precursors of the Hukbalahap guerilla movement in the countryside. Labor and peasant unrest occurred across the country (McCoy, 2009). The more organized guerilla movement, the Hukbalahap, after successfully battling the Japanese for years, staged a campaign against the US and the Philippine Government from 1945 to 1952 (Greenberg, 1986, Salonga, 2000). As one major from the US army put it, "the Huk guerillas grew in size and efficiency throughout the way, emerging at its conclusion as a well-trained, highly organized force numbering some 15,000 fighters and capable of threatening the Philippine government" (Greenberg, 1986: 16-17). Fighting erupted across the country, making it difficult for business to appropriate cheap basic inputs (Brimo, 1953, 1951). 


\section{National Developmentalism (1945-1964)}

During the Japanese occupation of the Philippines, a significant amount of mine infrastructure was destroyed (Brimo, 1953). The Philippines gained its independence in 1945, but efforts to restore the sector were influenced by the strong nationalist sentiments of elites. There would be substantial state intervention in the economy: laws were put in place to support domestic business groups, enhance internal trade, and control the outflow of foreign financial reserves (Holden, 2005, Lopez 1992). It was under these conditions that some mining companies were nationalized and purchased by indigenous groups during the 1950s. Philippine-owned mining companies such as Benguet, Atlas, Marcopper, Lepanto, and Philex were also established and began to export minerals to Japan (Marzan et al. 2010, Holden 2005).

Postwar Philippines instituted import controls. This led to foreign investors eventually losing out to Philippine elites in some major sectors (Brimo 1953, Hoskins, 1950, O'Connor, 1998, Wallerstein, 1974). Foreign companies sought to reconstruct mines but because of parity rights, citizen requirements, and state support for nationalization, the land needed to do so was expensive. Antonio Varias, a leading expert on land at the time, argued that land prices in the country were higher compared with some cities in America because of the nationality requirements and the cost of shipping bulldozers, road-rollers, trucks, gasoline and oil, tools, and other materials (Varias, 1955), which made it difficult for mine infrastructure to be built in the provinces. Labor also became more expensive because of nationalization laws that made the private sector pay workers relatively reasonable wages with benefits to keep up with inflation (Brimo, 1953, Sanders, 1963b). Nestor Lim, the Secretary of the Chamber of Mines, complained that higher taxes were harming the rehabilitation of the industry after the war (Lim, 1949). He also noted that machinery, spare parts, and mine supplies had gone up from $20 \%$ to $110 \%$ in the final two months of 1949 , and that import controls hamstrung efforts to acquire mining technology from abroad (Sanders, 1963a, 1963b).

Exchange control regimes also distorted the profitability of foreign mining companies and the growth of the mining sector in the country. When M.R. Arick, Vice President of Lepanto Consolidated Mining Corporation, wanted to build a mill on June 26, 1948, he needed to borrow money covered with onerous payment conditions. By 1949, he was already in debt by US $\$ 1.5$ million, which had US $\$ 300,000$ carried over from 1941 (Arick, 1958: 11). In 1958, he accused the Central Bank of confiscating the dollar earnings of the mining industry to support import manufacturing in the country. The Central Bank was deliberately exchanging 
the P2.00 for US\$1.00, making it difficult for mining companies to acquire more technologies and finance more exploration projects (Arick, 1958). Despite having to deal with the higher political cost, as the Senate and Congress were threatening to impose taxes on mining licenses, corporate tax, and real estate (O'Connor, 1998, Sanders, 1963a, Wallerstein, 1974), silver and gold, as well as base metal production, had acceptable profits: precious and base metal production was still earning at least US\$1-2 million a month.

The mining sector recovered reasonably, but it was not as profitable as it was in the 1930 s. National developmentalism was expressed through policies that made it advantageous for Philippine nationals to own mines and invest in land, consistent with the nationalist fervor and generally helpful to the state's reproduction of the political order (Kerkvliet 1986, Salonga, 2000). Strong nationalist sentiments, however, did not mean that the Philippines exercised considerable independence after 1945, but rather that its economic regime was more complicated than a simplistic notion of neocolonial imposition. Indeed, the mining sector did not have considerable influence in the 1950s, but agricultural cash-crop interest for domestic elites did. Philippine independence, then, meant that the bureaucratic structures could not remain fully servile to the US Government and that import and export controls created a vacillating Philippine Government: between state-led industrialization and import substitution (ISI) and the export of primary commodities. The Bell Trade Act and other postwar treaties created preferential markets for Philippine agriculture, ${ }^{13}$ emboldening the elites to expand their coconut and copra lands to target the US markets and allowing them to maintain profitability for a significant period of time. The mining sector was forced to take a back seat to the more powerful agricultural interest.

Cash-crop production and agriculture continued in the rural areas. During the period 19451960, however, the vast land, accessible resources, and "cheap natures" needed to reconstruct the mining industry from the war were largely inaccessible. There were decreasing returns in the mining areas of Benguet, Bicol, Mt. Province, Romblon, and many other areas because of years of extraction (Brimo, 1953, Sanders, 1961b). Mining companies needed to expand mining operations inward, but their efforts to do so were hampered by a dearth of roads, rail transportation, and waterways (Arick, 1948, 1958, Brimo, 1961, Sanders, 1963). The Chamber of Mines complained that the inner, more mountainous areas were more problematic because of security concerns and transaction and transportation costs (American

13 The act maintained preferential access to Philippine agricultural products in US markets. However, there were increasing taxes imposed on agricultural exports every five years. 
Chamber of Commerce, 1948, 1958, Brimo, 1961). As the Philippine government continued to support the export of agricultural products, a weaker peso vis-à-vis the dollar became priority for exports to be competitive. By implication, the weaker Philippine peso meant expensive imports of machinery and technology. Industrial sectors and the mineral industry were concerned with heavy taxes levies and expensive expansion cost, which discouraged foreign investors from capitalizing much further (Arick, 1958).

Although the Hukbalahaps were defeated in the mid-1950s through US support, specifically the funding and arming the Philippine military (Greenberg, 1987), security concerns with the birth of the Communist Party of the Philippines (CPP) in the late 1950s fuelled more militarization in the area, diminishing investor enthusiasm even further (Brimo, 1961, Sanders, 1963a, 1963b). Low rice production in the 1960s, the dispossession of peasants from the lumber industry, and the political infighting of political dynasties, restricted the expansion of the mining industry. As peasants suffered from food self-sufficiency, the CPP grew in numbers and support. Militarization and violence made the operational cost of labor and food more expensive for the mining companies (Brimo, 1961, Sanders, 1963a). The expanding timber and agricultural frontiers, the problems of security, decreasing returns, along with the political obstacles of national patrimony in industries prevented the mining industry from expanding, quite unlike its heyday in the 1930s (Sanders 1963).

The multiple and contradictory expressions of commodity frontiers in competing economic sectors along with the political cost of national patrimony led to the mining sector's "sick man" status from 1945 to 1964 (Lopez, 1992). In December 1957, Carlos P. Garcia gave a speech highlighting the importance of mining precious and base minerals in the country. He stated that "the problem of dollar reserves and the expansion of the mineral industry were clear," and furthermore signaled the need for foreign investment to "work and make mining the biggest of industries" (American Chamber of Commerce, 1958: 3). As he put it the time, the Philippines "can no longer generate developmental funds from sources other than taxes and the proceeds of our present exports. Development loans can be liquidated by the same industries they are intended to sustain" (American Chamber of Commerce, 1958: 6). The mining sector had to wait for the Ferdinand Marcos state-led mineral regime, altering the rules of the game in favor of large-scale mining through state-facilitated incentives and lowinterest US commercial loans (Holden 2005, Lopez 1992). 


\section{State Authoritarianism (1965-1985)}

Following the postwar period, very low and negative interest rate loans were made available to developing countries to pursue state-led industrialization (Harvey 2006). Many Latin American, African, and Asian countries were able to borrow money on the international market and from private banks (Bello 2009, Harvey 2006, Panitch \& Gindin, 2012). Developing countries were caught in a cycle of borrowing cheaply, constructing industries, exporting commodities to the world market, and paying loans back quickly (Panitch \& Gindin, 2012). During the Marcos period, the rise of a state-led mining regime commenced in the Philippines, initially on the back of borrowed surplus capital from US commercial banks. Mine infrastructure similarly facilitated by the Philippine Government was lent to domestic firms (Lopez, 1992): Marcocopper borrowed US\$4 million dollars in 1968; Lepanto borrowed US\$3 million; and Benguet borrowed a total of US\$1.5 in the 1970s (Brimo 1968, Lopez, 1992). Further capitalization, then, sparked the expansion of mineral frontiers that were untapped during the postwar period, leading to the construction of roads, bridges, and supply lines between ports and the mines.

At the policymaking level, Marcos sought a state-led regime through the capitalization of domestic firms and aggressive promotion of mineral exploration in peripheral regions. From a sector that relied on foreign investments and speculative capital, Marcos shifted the mining regime toward an "active, state-led" development model in 1974 (Bowie and Unger, 1997, Lopez 1992). Presidential Decree 464 favored large, established business interests that could mobilize financial resources to explore, develop, and exploit minerals. By giving tax holidays and increasing collaboration between the state and business, Marcos provided cheap commercial loans from US domestic banks and granted tax holidays to Philippine mining companies. The active capitalization of large-scale domestic mining industries also meant restricting foreign ownership (e.g., a cap of $40 \%$ equity ownership in companies), effectively ensuring domestic majority ownership of mining companies (Bowie \& Unger 1997, Lopez 1992). Figure 2 shows the breadth of mining and industrial development more generally in the Philippines in 1973. 
Figure 2: Industrial development, 1973, during the Marcos Regime

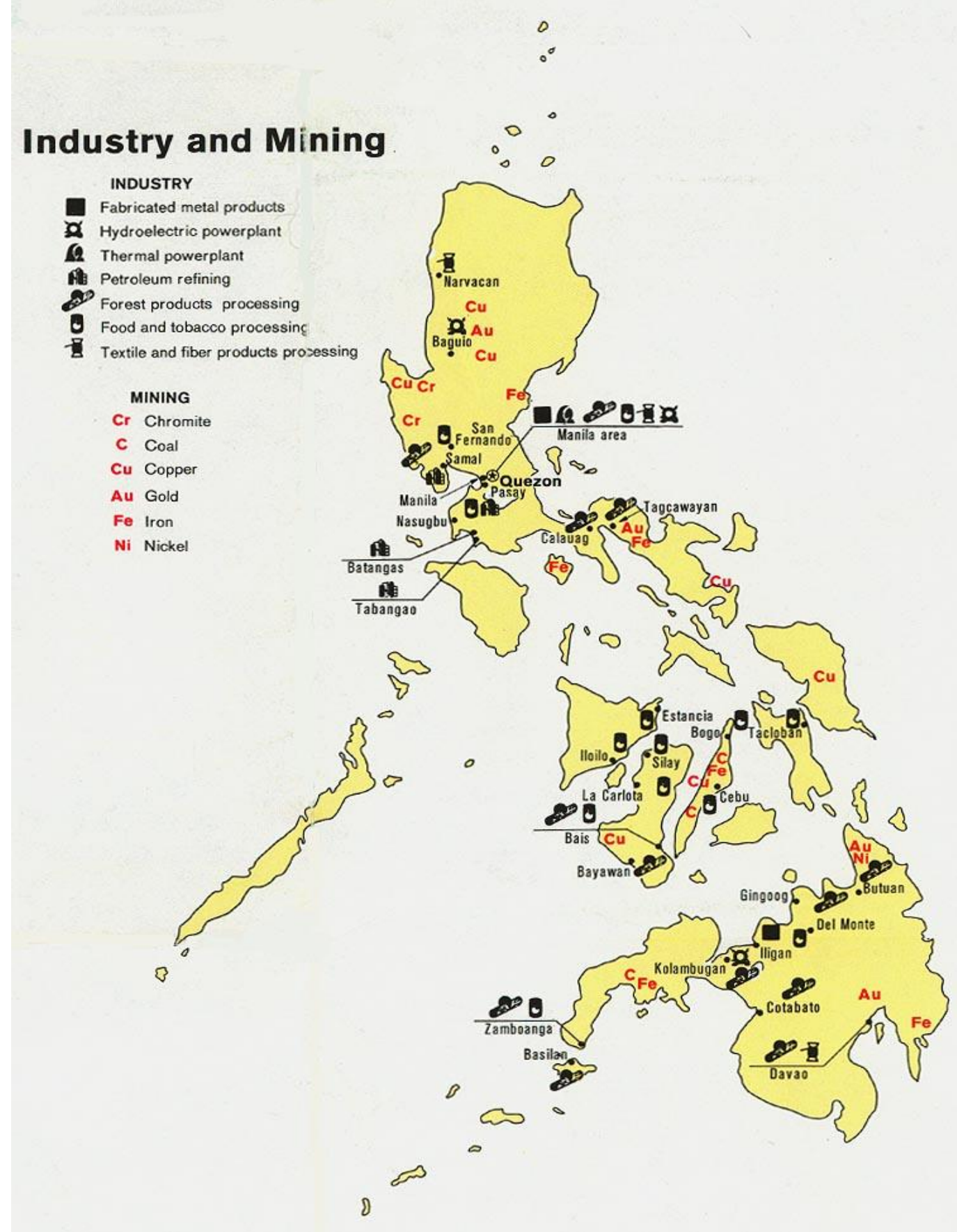

Source: Central Intelligence Agency, 1973

Marcos benefited from the gradual development of economic infrastructure and the state's capacity to appropriate resources. Most of these efforts started during the postwar period, but Marcos's mineral regime benefited from the buildup. From 1945 to the 1960 s, water was 
a problem for peasants and landlords producing rice. The irrigated rice crop barely increased in the 1950 s, but it "rose from $24 \%$ in 1959 to $45 \%$ in 1969-1971" (Bello 2009, 114). A land reform bill was implemented in 1965 to improve state investment in land; it led to the distribution of a variety of seeds to improve yields (Quimpo, 2007, Salonga, 2000, Tiglao, 1988). Mechanization in the form of tractors, power tillers, and rotary wheelers improved rice production (Bello, 2009, Tiglao, 1988). Investment in agriculture stabilized and provided employment in rural areas (Manapat 1991, Quimpo, 2007), making it easier for mining companies to explore for potential mineral areas and develop new projects. Crop diversification and less focus on cash crops through rice intensification led to the stabilization of food prices for peasants. Further, Marcos secured the region through his firm control of the military, making sure that separatist and revolutionary movements remained dormant (Rempel, 1993). In short, the appropriated basic inputs or "cheap natures" allowed mining companies to explore and extract minerals more securely.

The 1970s signified the height of the mining industry in the Philippines, highlighted by the opening of the first copper deposit in Cebu by the Atlas Mining Company (Marzan et al. 2010, Bowie and Unger, 1997). Along with significant high-grade iron deposits, nickel from the Nonoc mines of Surigao and the Rio-tuba mine in Palawan, copper became one of the most important mineral exports of the Marcos regime (Bowie \& Unger, 1997, Lopez, 1992). Despite Marcos' "activate, state-led" model, foreign investors were still key players in the mining sector, as they possessed minority shares in the major companies. Minerals and other natural resources were extracted and mostly exported to Japan and Korea: copper, zinc, and nickel prices were below the historical average per ton (Gomez, 2012, Marzan et al. 2010). Copper, magnesium, chromite, and zinc helped the vertically-integrated Japanese Keiretsu, which had heavy investments on automobiles and machinery (Broad, 1997, Bowie \& Unger, 1997, Seagrave, 1998). High-value sectors based on state-led industrialization stabilized East Asian economies and reinforced the developed world's position in its rivalry with communist states.

The Philippines, however, benefited very little from this relationship, acting instead as a resource basin for industrializing East Asian states. One-fifth of Philippine exports contributed only $1-1.5 \%$ of gross domestic product (GDP) during the peak of mine production (Israel, 2011). In the overall total exports of $1,062,000$ articles in 1970, the Philippines exported 220,503 mineral products. While mined products represented a considerable $20.76 \%$ of overall exports, they only contributed 1.15 Global Value Added (GVA) to Philippine GDP (Israel, 2010, 2011). In 1980, considered to be one of the most productive mining years of 
in the Marcos era, 1,234,786 mineral products were exported out of a total of $5,787,788$ articles. However, even with a share of $21.33 \%$ of total exports, mineral products only contributed to $1.50 \%$ of GDP (Israel, 2010, 2011). Although initially delivering promising numbers with an average growth rate of $6.02 \%$ GVA from 1970 to 1979, the GVA fell to $1.66 \%$ from 1980 to 1989 (Israel, 2010). Of the 39 companies operating in the 1980s, only 16 remained at the end of the Marcos period (Israel, 2010). In addition, while the share of mineral exports to Philippine exports grew between 1975 and 1980, from $17.33 \%$ to $21.33 \%$ (Gomez, 2012, Israel, 2010), GVA fell. Alongside the absence of an appropriate system of accounting for minerals in its ports, leaving this responsibility to the Japanese or Taiwanese, the export system created opportunities for the acquisition of minerals at prices far lower than the global market prices and fuelled the rent-seeking activities of local officials (Bowie \& Unger, 1997). By the end of the 1980s, the rise of the East Asian Tigers and their visible material growth helped to stabilize Western capitalism's legitimacy across the globe and discredited the influence of the Soviet and Maoist regimes (Arrigh 1994, Bunker, 1984). The "Tigers" of East Asia, therefore, owed some of their success to the quasi-colonial domination of the Philippines and the eventual willingness of Marcos to participate in this interstitial hierarchy of the division of labor.

Figure 3: Percentage Share of Minerals Exports to Total Exports

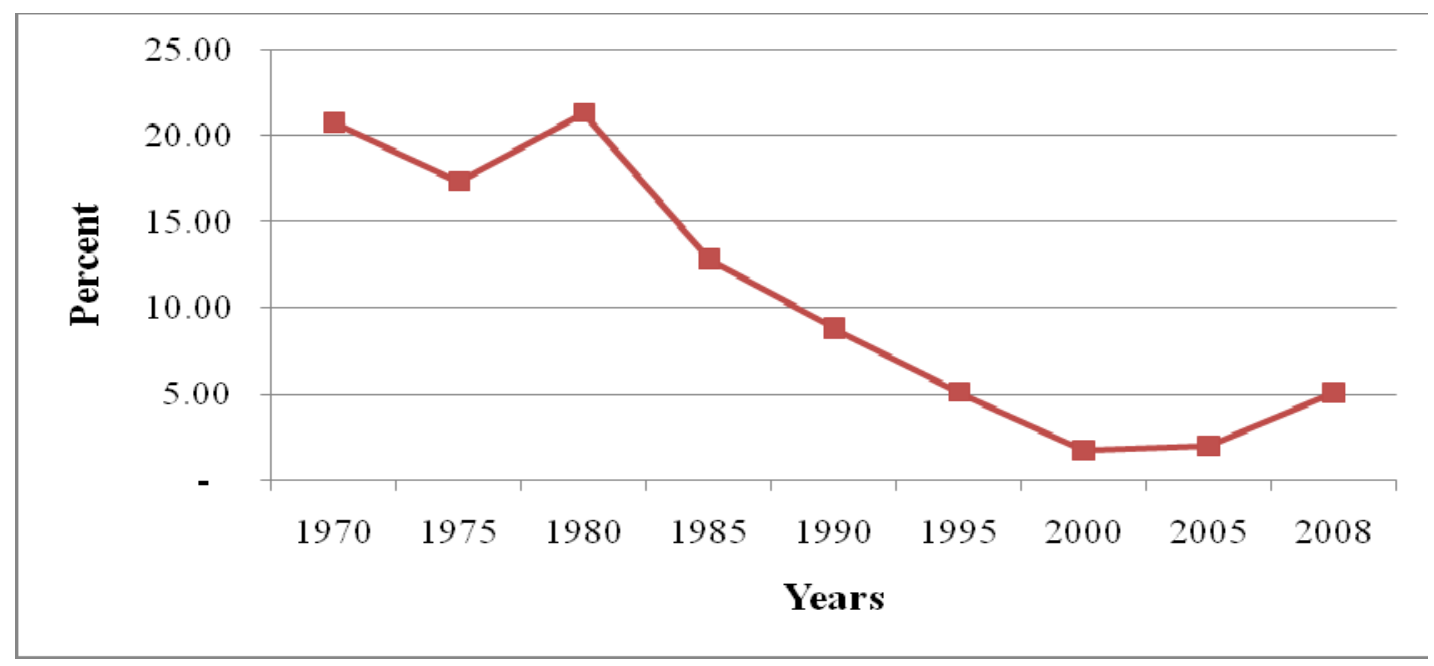

Source: Israel, 2010

The rising costs of appropriation in part expedited the end of the state's authoritarian regime. It is true that rural infrastructure improved through low-interest loans and state expenditure: 
total land area irrigated, which was 500,000 hectares in the mid-1960s, reached 1.3 million hectares by the mid-1980s (Seagrave, 1988, Rempel, 1993, Tiglao, 1988). However, Marcos's land reform program and rural infrastructure benefited mostly the medium and large farms, alienating the peasants much more and exacerbating the asymmetric distribution of economic rents (Aquino, 1999, Bello, 2009, Salonga, 2000). Much of the growing yields gave way to sugar, coconut, pineapple, and banana exports, limiting rice production once again (Celoza, 1977, Tiglao, 1988). State irrigation programs also increased reliance on high-yield, chemicalintensive fertilizers, herbicides, and seed varieties, boosting the rural outputs in the short term, from 1965 to the 1980s, although the rising costs of chemical-intensive growth eventually led to declining returns (Bello, 2009, Rempel, 1993, Seagrave, 1988).

The World Bank's structural adjustment program at the end of the 1970s caused a massive expropriation of state industries and state-supported agriculture. Tariffs were lowered from $47 \%$ to $20 \%$, causing the collapse of many industries (textiles, ceramics, rubber, petrochemicals, wood, shoes, petroleum, and oil) and massive unemployment (Aquino, 1999, Bello, 2009, Rempel, 1993). Most of the displaced or dispossessed went to the cities, but others went upland. Debt servicing from $8 \%$ to $10 \%$ of Philippine GDP led to less state domestic spending, ${ }^{14}$ leading to the contraction of an already-unequal agricultural industry (Salonga, 2000, Tiglao, 1988). (Tiglao, 1988). In the mid-1960s, Marcos's spending was at $7.5 \%$ of the GDP for state services, but it fell to $3.3 \%$ at the end of his reign. Of the 4.7 million hectares of agricultural land, 1.3 million stagnated because of a lack of government support, which relied on funds from low-interest loans (Aquino 1999, Rempel, 1993). In the 1980s, food and labor costs rose (Ibon, 1980); approximately $90 \%$ of laborers were paid wages below minimum wage (Ibon, 1980); more peasants in rural areas became impoverished and ended up joining the New People's Army (NPA) (Salonga 2000, Tiglao, 1988).

As the United States devalued the dollar, making their exports and own products more competitive, the so-called Volcker shock raised US interest rates above the world market average, which tripled almost overnight (Panitch and Gindin, 2012). Development projects in the Third World were delayed and abandoned after 1979 because of an inability to access capital for reinvestment (Bello et al. 2005), and "cheap money" was no longer available to fund existing mining operations or to explore more mineral-rich areas. ${ }^{15}$ In the $1980 \mathrm{~s}$,

\footnotetext{
${ }^{14}$ Debt rose from $\$ 2$ billion in 1972 to $\$ 25$ billion in 1983 (Tiglao, 1988).

15 The shock stimulated a movement of capital from development projects in the Third World into the banks of New York and San Francisco (Arrighi, 1994, Harvey 2003, Gindin and Panitch, 2012, Brenner, 2006,). With the US Fed's
} 
Western and Japanese mining capital was redirected into Latin America (Bunker, 1984, 1985). As such, Marcos's state-led mining regime could not sustain the large foreign investments necessary for its existence. Although initial growth in the regime could be attributed to the investment of domestic business interest with links to the authoritarian regime, Marcos failed to entice companies to invest further in mineral exploration because of restrictions imposed on foreign ownership. The most accessible and cost-effective mines had been worked first; the deeper and more difficult mineralized areas needed more investment and technologies to develop (Bunker, 2005). ${ }^{16}$

Numerous environmental accidents occurred at state-supported mining operations (Marzan et al., 2010). The Marcopper Company, in which Marcos himself was a key shareholder, left mineral tailings in Calancan Bay that affected the livelihoods and health of residents in surrounding communities. From 1975 to 2001, approximately 200 million tons of mine tailings were deposited in the bay, upon which 20,000 people relied for their livelihood (Marzan et al. 2010, Thomspon, 1996, Lopez, 1992). Several large corporations have been found guilty of depositing their tailing deposits in aquatic bodies: Philippine Pyrite Corporation in Western Samar from 1956 to 1992, Basay Mining Corporation in Negros Oriental from 1978 to 1994, Consolidated Mines in Marindique from 1977 to 1979, and Western Minolco Corporation in Benguet from 1974 to 1982 (Marzan et al. 2010, Lopez 1992). Mineral tailings led to water pollution, lake poisoning, and the death of aquatic life in water bodies (Celoza, 1997). Despite these numerous health hazards, communities continued to provide secondary services to the large mining corporations. These services included labor for the construction of infrastructure, home cooked food for workers, and materials for other needs (Lopez 1992). Additionally, as the mineral regime started to crumble with the fall of Marcos, towns that relied on mining slowly depopulated (Lopez 1992).

The developments in the 1980 s and the inability of the state to appropriate "cheap natures" empowered resistance movements. The persistence of the CPP and its armed wing, the NPA, had become a serious threat by the end of the 1980s. Estimates at the time project the insurgents to have reached numbers of at least 25,000 fighters, which proved to be a serious enough threat to Manila by the mid-1980s (Tiglao, 1988). From various ecological problems

closure of the gold window in 1979, changes in the world economy led to further abandonment of the Bretton Woods era of fixed exchange rates. Private international capital flows were, similarly, dwarfed by the public capital flows of the International Financial Institutions and states (Peters, 2010, Wade 2006, Krippner, 2005). As industries in the Third World could no longer earn capital profitably because of the absence of US commercial loans, the demand for minerals also decreased during the 1980s (Lopez, 1992).

${ }_{16}$ Author interview with the non-executive director, Indophil Resources Philippines, Mandaluyong, Philippines, June 3,2010 . 
to intra-provincial warfare between the Philippine military and the NPA, numerous communities and indigenous groups have been displaced throughout the country. (Aquino, 1999, Tiglao 1988). Indeed, during the most violent days of the regime, communist insurgents assaulted mining operations (Lopez 1992). People's organizations and indigenous groups protested against the expansion of mines through Marcos's rule and did not stop until his fall (Tiglao, 1988, Thompson, 1996). In sum, the cost of doing business in the Philippines became exuberantly more expensive because of the rising cost of cheap inputs and security issues.

Recognition of the socio-ecological consequences of mining spawned political debates (Holden, 2005, Lopez, 1992). In the 1980s, state-led projects in the Philippines, such as the Chico Dam project, Bataan Nuclear Power Plant, as well as state-supported mines, expelled entire populations from their towns, generated significant ecological waste, and failed on a public relations front (Marzan et al. 2010). In the mining sector, medium-size companies closed and larger Philippine-owned companies reduced in size and/or closed their operations to cut losses, streamlining their business interests in exploration and exploitation, thus yielding very little income. The GVA of Philippine mining started to decline between 1981 and 1984, from $17.92 \%$ to $9.57 \%$ and mineral exports fell from $1,025,489$ to 516,054 (Israel, 2010). By 1984, it was clear that not only would mining fail to deliver economic growth (see Figure 3) but that it was also responsible for disastrous environmental and social impacts that would spark public resentment toward the industry (Lopez, 1992).

\section{The Neoliberal Regime (1986-present)}

Following the fall of the state-led mineral regime, small-scale mining began to expand across the country. Mines were abandoned by the state and corporations (Marzan et al. 2010), resulting in large-scale population displacement and unemployment. Small-scale miners in pursuit of gold, funded by local politicians and capitalists, proliferated in the newly-abandoned mines, most notably in Mount Diwalwal, which had already attracted 150,000 small-scale miners in the mid-1980s (Orfenio, 2009, Lopez, 1992). Small-scale miners began to extract and sell undervalued minerals through illegal exports and smuggled contraband. Mining, therefore, had become a part of the informal economy, guided by the logic of flexible accumulation. Local investors and new mining companies started acquiring potential mineral areas without investing in exploration and extraction. As an executive from a major mining company noted, "a lot of very promising mineral areas ... [have been] held hostage to really 
greedy and outrageous demands from people."17 These investors were instead speculating on the eventual increase of the price of potential mineralized lands.

As the United States abandoned its commitment to gold and promoted currency flexibility, private capital flows fuelled competition in more than 90 countries through new mining codes, with the aim of capturing FDI (Nem Singh, 2012, Nem Singh and Bourgoin, 2013). The policy alterations took place at a time when resource investment was intensifying in the developing world, partly as a result of Chinese economic growth and China's search for minerals, but also due to the restructuring of the global extractive industry that pushed investments toward resource-rich countries with low taxes and pro-foreign investment regimes (Nem Singh and Bourgouin, 2013, World Investment Report, 2007). The rush to compete for investments in exploration and extraction resulted in patchy acquisition without exploration of various lands by mining companies. ${ }^{18}$ As mining is capital-intensive, foreign mining companies did not want to invest unless put in advantageous positions (Humphreys, 2009).

In an effort to incorporate small-scale activities in the formal economy, the Philippine Government began to institute neoliberal policies as early as 1986 . The first phase of neoliberal mining unfolded through Aquino's commitments toward an architecture of governance based on large-scale mining, with FDI at the core of its development strategy. However, it was in Ramos's term that the new mining law was passed, allowing foreign capital to operate more freely within the country. The Philippine Mining Act was finally approved by Congress in 1995, signifying, in large measure, a clear policy response to the growing calls of foreign investors to reduce uncertainties in the high-risk extractive industries (Ali, 2003, Gomez 2012, Vivoda 2008). At the end of his term in 1997, an impressive national campaign toward constitutional change to lift ownership limitations in the constitution was viewed as a hindrance to future large-scale investment in the country (Batongbacal, 2011, Gomez 2010, Vivoda, 2008). However, Ramos's legacy would take off once Gloria Macapagal-Arroyo (20012010) became president after a middle-class-led protest against Joseph Estrada (19982001). Macapagal-Arroyo attempted to revive the country's mining sector: employing the same neoliberal framework, she reversed the Supreme Court's decision to halt large-scale mining and issued Executive Order 270 (EO 270), along with the Mineral Action Plan.

\footnotetext{
17 Author interview with the non-executive director, Quezon City, Philippines, June 3, 2010.

${ }_{18}$ Author interview with the mining consultant, Geograce Resource Philippines, Quezon City, Philippines,

December 31, 2009.
} 
As seen in figure 4, these policy changes signaled a renewed focus from the state toward a resource-based developmental strategy embedded within a neoliberal policy paradigm. The neoliberal regime initiated a race for the archipelago's reserves (worth between US $\$ 850$ billion and US\$1 trillion) valued at 10 times the country's annual GDP and 15 times its total foreign debt (Mines and Geosciences Bureau 2013, Philippine Government, 2010). Between 1994 and 1996 alone, the number of foreign mining companies represented in the country increased by 400\% (Holden and Ingelson, 2007). By 2005, the government had approved 180 Mineral Production Sharing Agreements, 70 Exploration Permits, 126 Industrial Sand and Gravel Permits, and five Special Mineral Extraction Permits (Mines and Geosciences Bureau 2013, Rovillos et al. 2012,194). In 2010, the country had the second largest number of explorations sites in the Asia-Pacific region (World Investment Report, 2007). With key players such as Xstrata, Indophil Resources, and Philex Mining Corp (an affiliate of TVI Pacific Inc.), the mining and quarrying sector today represents about 33\% of total FDI in the country (World Investment Report, 2007). Together, the 27 large-scale mines in the country accounted for US $\$ 2.7$ billion in exports in 2011 (Holden, 2005). Even though total metal mining operations increased from 23 in 2008 to 35 in 2012, approved mining contracts soared from 545 in 2008 to 730 in 2012 (MIB, 2013). Mineral investment's share of total investment remained low at $2.58 \%$ in 2000 , but rose to $12.54 \%$ by $2008 .{ }^{19}$ The export of raw materials, with mining as its core, has figured prominently in national economic strategy.

\footnotetext{
19 Industry experts have argued that mining investments have been underestimated because of the interlocking, complementary functions of the sector with manufacturing and consumer goods. Further, mining investments come in big bouts and spurts. In 2013, mining contributed US $\$ 718$ million of total investment of US $\$ 3.86$ billion, barely reaching the level of US\$791 million investment reached in 2012.
} 
Figure 4: Priority Mineral Development Projects in the Neoliberal Period

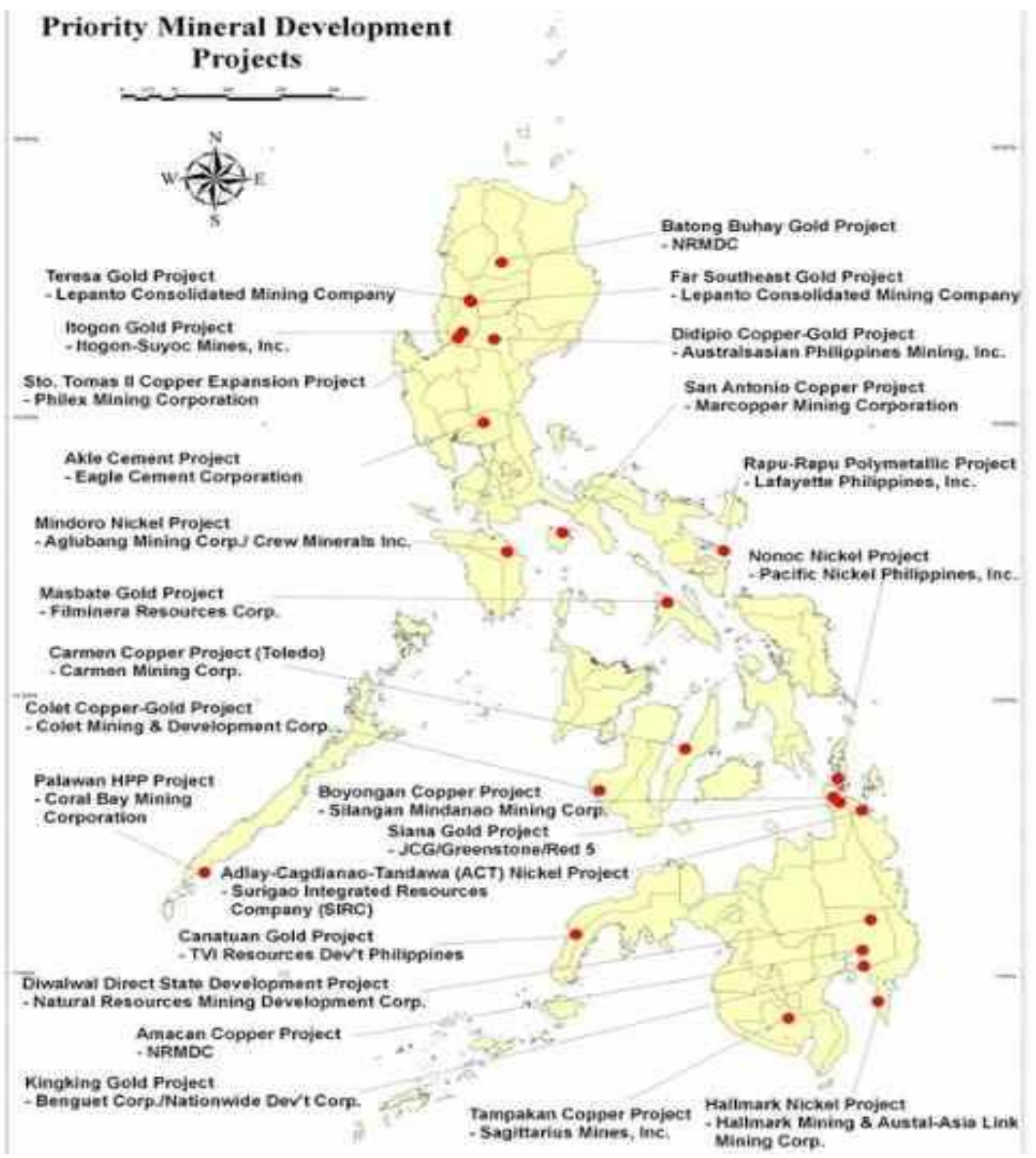

Source: MGB, 2006

Financialization played a big role in the movement of mining companies across the country. In 2013, Glen Core Xstrata was offered US\$17.3 billion in revolving credit facilities with very low interest rates (Reilly, 2013). The company opened business opportunities in the Philippines with revenue of US $\$ 214$ billion through trading coal, oil, copper, and maize. Glen Core Xstrata is one of the biggest investors in the Tampakan gold mines, with a majority 
share of $62.5 \%$ in a $40 \%$ controlling stake (Barrick Gold, 2012). Indophil Resources received funding from the Alson Group, backed by BDO Unibank, the financial arm of the SM Group, one of the biggest capitalist conglomerates in the Philippines (Indophil, 2011). In 2013, TVI Pacific received a US $\$ 23$ million loan project to develop its Balabag gold-silver project in Mindanao. Metropolitan Bank \& Trust Co. provided this loan under the condition of the mineral production sharing agreement by TVI (TVI, 2013). The role of speculative activities is perhaps more pervasive. Hedging increases the price of gold, leading to the rush to extract gold legally or illegally.

As capital moves in the potential mining areas, the displacements, the rising cost of food, and unfair deals given communities started to fuel anti-mining resentments. Accompanying the disempowerment of indigenous groups and communities have been abuses. They have been linked to the activities of transnational companies: Toronto Ventures' relentless expansion in the Subanen province; Western Mining Corporation's FTAA covering of 94,400 hectares of indigenous land belonging to the Tagalaulo, B'laan and Manobos (Alyansa Tigil Mina 2011a, Philippine Congress, 2013); and a consortium of companies that had the FTAA of the town of the Midsalip group in Zamboanga Del Sur (Foster, 2012, Philippine Congress, 2013). Extortion and abuses have been rampant among the Civilian Armed Military Forces (CAFGU) units, the de facto paramilitary security apparatus of the mining companies (Vivoda 2008, Rovillos, et al. 2003). Furthermore, Western Mining Company in Southern Mindanao reportedly bribed the Salnaon banwu, a community of ethnic B'laan and the Denlegs (Alyansa Tigil Mina, 2011a, Philippine Congress, 2013). Extrajudicial assassinations of anti-mining activists and journalists were known tohave taken place across the country during the rule of Gloria Macapagal-Arroyo (2001-2009).

The neoliberal regime continues to vacillate between flexible accumulation of small-scale mining and large-scale mining. ${ }^{20}$ Large-scale and small-scale mining, however, both play huge roles in the export of minerals partly because of Chinese demand. ${ }^{21}$ Both modes may be different, but they appropriate "cheap natures" and function similarly when it comes to capital accumulation. Tampakan mining, for example, has been known to be a "mountain of death," inhabited by competing and sometimes colluding mining companies (Marzan et. al, 2010, Molintas, 2004, Philippine Congress, 2013, Rovillos et. al, 2003), local governments, state agents, and communities. By exporting gold to the global market through informal small-

\footnotetext{
${ }^{20}$ Author interview with a former local government unit official, Bayombong, Nueva Vizcaya, June 26, 2014.

${ }^{21}$ Author interview with a mining consultant, Geograce Resource Philippines, Quezon City, December 31, 2009.
} 
scale mining, some of these actors seek to capitalize on the rising price of gold in global stocks. ${ }^{22}$

\section{Conclusion}

Research on state autonomy and institutional capacity of extractive regimes has informed a growing body of scholarly literature on the nature of the state and state-economic relations in the Southeast Asian political economy (Kuhonta 2011, Slater 2010, Vu 2010a, 2010b). The paper contributes to this debate by analyzing how extractive sectors are formed by changing relations in the global political economy. Using a longer-term historical framework, I explain how the appropriation of "cheap natures" intersects with sectoral development, and, in so doing, offer an empirical case that shows how the growth of the formal economy has come to depend on the appropriation of basic inputs or "cheap natures." However, this is more complex than simply a story of exploitation and plunder. The fall of mineral regimes shows the ways in which economic growth can be contradictory because of the decreasing returns from cheap inputs and the production of new natures. It also challenges the focus on institutional capacity and a narrow conception of growth based on foreign investment and material income.

My contribution lies in explicating theoretically and grounding empirically the genesis, development, and fall of mineral regimes via changing global-local relations in three eras. I provide a nuanced understanding of what globalized frames around surplus capital and socioecological contradictions mean in particular national and local historical contexts, while examining the conditions that provide opportunities for global capital to reestablish its conditions of accumulation. To sum up, I hope to have shed some light on the importance of global relations in understanding economic development in contemporary Southeast Asian economies, drawing attention to the foundational logic of capital accumulation through "cheap natures" and surplus capital.

22 Author interview with Congressional staff, Philippine House of Representatives, Quezon City, Philippines, October $19,2013$. 


\section{Acknowledgements}

Initial versions of the article were presented at the 2014 Annual Meeting of the Eastern Sociological Society, the 2014 Annual Meeting of the American Sociological Association, and at the $4^{\text {th }}$ Bi-Annual Binghamton Graduate Student Conference on Historical Social Science in Binghamton University (2014). I would like to thank Jason Moore, Gavin Hilson, Joanna Sta. Isabel, Roberto Ortiz, and Ben Marley, for conversations and correspondences on themes explored in the article. 


\section{References}

American Chamber of Commerce. 1929. 'P.I. Gold Exports.' May, 9.

American Chamber of Commerce. 1936a. 'Men of the Mines.' July, 34-3.

American Chamber of Commerce. 1936b. 'Men, Yen, and Machines.' November, 43.

American Chamber of Commerce. 1936c. 'New Act Creating Philippine Bureau of Mines.' October, 1-16.

American Chamber of Commerce. 1936d. 'The New Philippine Mining Act Marginally Indexed.' October, 17.

American Chamber of Commerce. 1936e. 'The Abra Mining District.' October, 25.

American Chamber of Commerce. 1936f. 'Antamok Goldfield: Third Largest Producer.' November, 31.

American Chamber of Commerce. 1937a. 'Base Metal Potentialities.' April, 21.

American Chamber of Commerce. 1937b. 'Treasure Island.' January, 23.

American Chamber of Commerce. 1937c. 'Men of the Mines.' 1937, 34.

American Chamber of Commerce. 1939a. 'Halfway in 1939.' August, 34.

American Chamber of Commerce. 1939b. 'What the Diggers Are Doing.' January, 23-24.

American Chamber of Commerce. 1948a. 'Editorial.' May, 153-154.

American Chamber of Commerce. 1958. 'Editorial.' January, 3-7.

Ali, S. 2003. Mining, the Environment, and Indigenous Development Conflicts. Tucson: The University of Arizona Press

Aquino, B. 1999. Politics of Plunder: The Philippines Under Marcos. Quezon City: University of the Philippines, National College of Public Administration and Governance

Araghi, Farshad. 1995. "Global Depeasantization, 1945-1990." The Sociological Quarterly, 36 (2), 337-368.

Araghi, Farshad. 2003. "Food Regimes and the Production of Value: Some Methodological Issues." The Journal of Peasant Studies, 30: 2, 41-70.

Araghi, Farshad. 2009a. "Accumulation by Displacement: Global Enclosures, Food Crisis, and the Ecological Contradictions of Capitalism." Review: A Journal of the Fernand Braudel Center, 113-146.

Araghi, Farshad. 2009b. "The Invisible Hand and Visible Foot: Peasants, Dispossession and Globalization." in Peasants and Globalization: Political Economy, Rural Transformations and the Agrarian Question edited by Akram-Lodhi and Cristóbal Kay. NY: Routledge. 
Araghi, Farshad 2010. "The End of 'Cheap Ecology' and the Crisis of 'Long

Keynesianism." Economic \& Political Weekly, Vol. XLV, No. 4: 39-41.

Arick, M.R. 1948. Lepanto Copper Mine Reopens. May, 155

Arick, M.R. 1958. The Mining Industry versus the "New and Necessary" Industries. January, 11-12.

Arrighi, Giovanni. 1994. The Long Twentieth Century. New York: Verso.

Batongbacal, J. 2011. "Steaming through Perilous Straits: Special Problems in Reforming and Rationalizing the Laws and Regulations for Philippine Offshore Petroleum Exploration and Development." Philippine Law Journal 85: 523-563.

Baran, Paul and Sweezy, Paul. Monopoly Capital. New York: Monthly Review Press, 1966.

Barrick Gold. 2012. "Barrick Reports Fourth Quarter and Full Year 2012 Results. Disciplined Capital Allocation to Drive Future Direction." Fourth Quarter and Year-End Report.

Bello, W., Docena, H., De Guzman, M. and Malig, M.L. (2005) The Anti-development State: The Political Economy of Permanent Crisis in the Philippines. Quezon City: University of the Philippines Press.

Bello, Walden. 2009. Food Wars. Verso.

Boericke, W. 1945. "Future of Philippine Mining." Geographical Society 14 (21): 300303.

Bowie, A. and D. Unger. 1997. The Politics of Open Economies: Indonesia, Malaysia, the Philippines, and Thailand. Cambridge: Cambridge University Press.

Brenner, R. 2006. The Economics of Global Turbulence. New York and London: Verso.

Brimo, H. 1953. "Mining." American Chamber of Commerce. March, 112

Brimo, H. 1961. "Mining." American Chamber of Commerce. April, 160

Brown, William Adam. 1929. England and the New Gold Standard, 1919-1926.

Bunker, Stephen G. 1984. "Modes of extraction, unequal exchange, and the progressive underdevelopment of an extreme periphery." American Journal of Sociology 89(5), 1017-1064.

Bunker, Stephen G. 1985. Underdeveloping the Amazon: Extraction, unequal exchange, and the failure of the modern state. University of Chicago Press.

Bunker, Stephen G. and Paul S. Ciccantell. 2005. Globalization and the Race for Resources. Baltimore: The Johns Hopkins University Press.

Burkett, P. 1999. Marx and nature. New York: St. Martin's Press. 
Burkett, P. 2003. Nature and value theory. Science and Society, 67(4), 452-62.

Cassell, Gustav. 1966. The Downfall of the Gold standard. A.M Kelley: New York.

Celoza, A. 1997. Ferdinand Marcos and the Philippines: The Political Economy of Authoritarianism. Ca: Praeger.

Census of the Philippine Islands. 1905. Taken Under the Direction of the Philippine Commission in the Year 1903. United States Bureau of Census, Washington

Census of the Philippine Islands. 1938. Commonwealth of the Philippines. Commission of Census, Manila.

Central Inteligence Angency. 1973. "Philippines - Industry and Mining." Map. No. 501475. Taken from the Perry \& Castenada Library Map Collection, http://www.lib.utexas.edu/maps/philippines.html, accessed February 22, 2015

Compliance Advisor Ombudsman (CAO). 2012. "IFC Investments in Mindoro Resources Limited." Cao Appraisal for Audit of IFC.

Diplomatic \& Consular Reports. 1909. "Phiippine Islands Map Showing Principal Mineral Districts." Annual 4369-4387, 1908. Vol. 7. Edited at the Foreign Office and the Board of Trade. London. 1909, from ftp://ftp.fu-berlin.de/misc/maps/pcl-mapcollection/historical/history asia.html , accessed February 22, 2015

De Cecco, Marcello. 1984. The International Gold Standard: Money and Empire. St. Martin's Press: New York

Flynn, John. 1937. "Iron, Copper, and Rearmament." American Chamber of Commerce. August, 20.

Federici, Silvia. 2012. Revolution at Point Zero, Housework, Reproduction, and the Feminist Struggle. Brooklyn: Common Press Notions.

Foster, George. 2012. "Foreign Investment and Indigenous Peoples: Options for Promoting Equilibrium between Economic Development and Indigenous Rights." Michigan Journal of International Law, 33 (4):628-691

Foster, John Bellamy. 1999. "Marx's Theory of Metabolic Rift: Classical Foundations for Environmental Sociology." American Journal of Sociology 105 (2), 366-405.

Foster, John Bellamy. 2008. "Peak Oil and Energy Imperialism." Monthly Review, 60 (3), 1-12.

Frank, Andrew Gunder. 1978. World Accumulation, 1492-1798. New York: Monthly Review Press.

Gallarotti, Giulio. 1995. The Anatomy of the International Monetary Regime: The Classical Gold Standard, 1880-1914. Oxford: Oxford University Press

Gallego, M. 1939. Economic Emancipation, An Independent View of Philippine Economic Problems and their Solution. Manila, Philippines. 
Gomez, M. 2010. "Transparency Issues in Philippine Mining, Toward Tax Justice

Framework." SOMO and Action for Economic Reform, Philippines: Quezon City, 1-26.

Goodland, R. and Wicks, C. 2009. Philippines: Mining or Food. Working Group on Mining in the Philippines, London.

Governor General. 1903. Report of the Governor General of the Philippine Islands.

Governor General. 1908. Report of the Governor General of the Philippine Islands.

Governor General. 1910. Report of the Governor General of the Philippine Islands.

Governor General. 1916. Report of the Governor General of the Philippine Islands.

Gomez, E.T. .2012. "State-Business Linkages in East Asia: The Developmental State, Neoliberalism and Enterprise Development." in East Asian Capitalism: Diversity, Continuity and Change, (eds.) Andrew Walter and Xiaoke Zhang, Oxford: Oxford University Press.

Gowen, Vincent. 1937. "Mountain Farmers and the Mining Prospects." American Chamber of Commerce. April, 20.

Greenberg, L.M. 1987. "The Hukbalahap Insurrection. A Case Study of a Successful AntiInsurgency Operation in the Philippines, 1946-1955." U.S Army Center of Military History, Analysis Branch. Washington, D.C.

Harvey, David. 2010. Enigma of Capital. Oxford: Oxford University Press.

Harvey David. 2013. A Companion to Marx's Capital Volume Two. London: Verso.

Harvey, David. 2006. The Limits to Capital. 2006. New York: Verso.

Holden, W.N. 2005. "Civil Society Opposition to Nonferrous Metals Mining in the Philippines." Voluntas. 16 (3), 223-249.

Holden, W. \& Ingelson, A. 2007. "Disconnect between the Philippine Mining investment Policy and Indigenous Peoples' Rights." Journal of Energy and Natural Resources L. 375

Hoskins, C.M. 1948. "Real Estate." April. American Chamber of Commerce

Hoskins, C.M. 1950. 'Real Estate.' May. American Chamber of Commerce

Ibon. 1980. "Facts \& Figures." December, 15.

Ingelson, A., W.N. Holden, and Bravante M, .2009. 'Philippine Environmental Impact Assessment, Mining, and Genuine Development.' Law, Environment, and Development Journal 5 (1): 1-15.

Israel, D. 2010. "National Industrialization in Philippine Mining: Review and Suggestions." Philippine Institute for Development Studies, Discussion Paper Series No. 2010-35, 1-51. 
Israel, D. 2011. "Value addition: the way of the future for Philippine mining." Philippine Institute for Development Studies, Policy Notes, 2011-18, 1-7.

Indophil Resources, NL. December. "Indophil announces US\$99.4m share placement linked to a strengthened strategic alliance." ASX Release.

Jernegan, P. 1907. The Philippine Citizen, A Text-Book of Civics, describing the nature of Government, The Philippine Government, and the rights and duties of citizens in the Philippines. Manila: Philippine Education Publishers.

Keeler, R. 1936a. "The First Half of 1936." July, 18.

Keeler, R. 1936b. "Looking Over the Philippine Mining Industry at the 1936 three-quarter mark." October, 17.

Keeler, R. 1937, Looking Back Over 1936. American Chamber of Commerce, January.

Kerkvliet, B. 1986. Everyday Politics in the Philippines: Class and Status Relations in a Central Luzon Village, Berkeley: University of California Friends

Kerkvliet, B. 1977. The Huk Rebellion: A Study of Peasant Revolt in the Philippines, Berkeley: University of California Press.

Krippner, Greta R. 2005. "The financialization of the American economy." SocioEconomic Review, 3 (2): 173-208.

Krippner, Greta R. 2011. Capitalizing on crisis: The political origins of the rise of finance. Harvard University Press.

La Vina, A, A. de Leon \& G.R. Bueta. 2012. 'Legal Responses to the Environmental Impact of Mining,' Philippine Law Journal 86 (4): 284-340.

Lim, N. 1951. "Mining." American Chamber of Commerce. December, 417.

Lopez, S. (1992) Isle of Gold: a History of Mining in the Philippines, Oxford: Oxford University Press.

Marley, Benjamin, and Samantha Fox. 2014. "Exhausting Socio-Ecological Relations: Conditions of Economic Viability in the Era of Mountaintop Removal in West Virginia," Journal of World-Systems Research 20 (2): 258-280.

Marzan, Anthony, et al. 2010. "CSO Assessment of the MTPDP (2006-2010)," Retrieved FromAlyansa Tigil Mina: alyansatigilmina.netMarx, Karl. 1973. Grundrisse. New York. Vintage

Marx. Karl. 1977. Capital. Vol. 1. New York. Vintage

Mines and Geosciences Bureau. 2006. "Priority Phippine Mineral Development Projects," Department of Environment and Natural Resources.

Mines and Geosciences Bureau. 2013. "Complete List of Mineral Sharing Production Agreement." Mining Tenements Management Division, Department of Environment and Natural Resources. 
Mines and Geosciences Bureau. 2013. "Mining Industry Statistics," Department of Environment and Natural Resources.

Manapat, R. 1991. Some are Smarter than Others: The History of Marcos' Crony Capitalism. Manila: Altheia Publications.

McCoy, Alfred. 2009. Policing American's Empire: The United States, the Philippines, and the Rise of the Surveillance State. Madison, Wisconsin: The University of Wisconsin Press.

Mitchell, T. 2013. Carbon Democracy. Political Power in the Age of Oil. London and New York: Verso. United Press. 1937, January. Metals Hit High Levels. The American Chamber of Commerce.

Molintas, J. 2004. "The Philippine Indigenous People's Struggle for Land and Life: Challenging Legal Text." Arizona

Moore, Jason W. 2000. "Sugar and the Expansion of the Early Modern World-Economy." Review 23 (3), 409-433

Moore, Jason W. 2008. "Ecological crises and the agrarian question in world-historical perspective." Monthly review 60 (6): 54-63.

Moore, Jason W. 2009. "Madeira, Sugar, \& the Conquest of Nature in the 'First' Sixteenth Century, Part I: From 'Island of Timber' to Sugar Revolution, 1420-1506." Review: A Journal of the Fernand Braudel Center 32 (4), 1-46.

Moore, Jason W. 2010a. "The End of the Road?: Agricultural Revolutions in the Capitalist World-Ecology, 1450-2010." Journal of Agrarian Change 10 (3), 389-413.

Moore, Jason W. 2010b. "Madeira, Sugar, \& the Conquest of Nature in the 'First' Sixteenth Century, Part II: From Local Crisis to Commodity Frontier, 1506-1530." Review: A Journal of the Fernand Braudel Center 33 (1), 1-24.

Moore, Jason W. 2010c. "The Lofty Mountain of Silver Could Conquest the Wole World": Potosí and the Political Ecology of Underdevelopment, 1545-1800.' Journal of Philosophical Economics 4 (1): 58-103

Moore, Jason W. 2011. "Ecology, Capital, and the Nature of Our Times: Accumulation and Crisis in the Capitalist World-Ecology." Journal of World-Systems Research 17, (1), 47-61.

Moore, Jason W. 2012. "Cheap Food \& Bad Money: Food, Frontiers, and Financialization in the Rise and Demise of Neoliberalism." Review, 33(2-3), 125-161.

Moore, Jason W. 2014a. "The Capitalocene, Part II: Abstract Social Nature and the Limits to Capital."

Moore, Jason W. 2014b. "The End of Cheap Nature or: How I Learned to Stop Worrying about 'the' Environment and Love the Crisis of Capitalism." in Structures of the World Political Economy and the Future of Global Conflict and Cooperation, edited by C. Suter and C. Chase-Dunn. Berlin: LIT, 285-314. 
Nem Singh, J.T. 2012. States, Markets and Labour Unions: The Political Economy of Oil and Copper in Brazil and Chile. PhD Dissertation, University of Sheffield, UK.

Nem Singh, J.T. \& F. Bourgouin. 2013. Resource Governance and Developmental States in the Global South: Critical International Political Economy Perspectives, Basingstoke: Palgrave Macmillan.

Nem Singh, J. and A. Camba. Forthcoming. "Neoliberalism, Resource Governance and the Everyday Politics of Protests in the Philippines" in Juanita Elias and Lena Rethal, editors, The Everyday Political Economy of Southeast Asia. Cambridge: Cambridge University Press.

O'Connor, J. 1998. Natural Causes: Essays in Ecological Marxism. The Guildford Press.

Ollman, B. 2003. "The Philosophy of Internal Relations." in Dance of the Dialectic. Urbana: University of Illinois Press, 36-50

Ortiz, Roberto José. 2014. "Agro-Industrialization, Petrodollar Recycling, and the Transformation of World Capitalism in the Long 1970s," Crit Sociol, July, 25.

Orfenio, R. 2009. "Failure to Launch: Industrialization in Metal-rich Philippines." Journal of the Asia Pacific Economy 14(2), 194-209.

Quimpo, N. 2007. Contested Democracy and the Left in the Philippines after Marcos. New Haven: Yale University of Southeast Asian Studies.

Philippine Congress (2013) "House Measures (National/Local) Primarily Referred to and/or Rules-Referred National Cultural Communities 2010-07-01 to 2013-06-30." Committee on Natural Cultural Communities, 16th Congress, Quezon City, 2013.

Philippine Government (2010) "A Wealth of Trade Opportunities in Mining," Philippines Consulate website. October 12, 2013 [Online] http://www.philcongenshanghai.org/mining.htm

Panitch, L. and Gindin, S. 2012. The Making of Global Capitalism: The Political Economy of American Empire. New York and London: Verso.

Peet, R. and Watt. M, 2004. Liberating Ecologies: Environment, Development, and Social Movements. London: Routledge.

Peluso, N. 1992. Rich Forests, Poor People: Resource Control and Resistance in Java. Berkeley, CA: University of California Press.

Reilly, A. 2013. "EMEA Loan: Glencore Xstrata's US\&17.34bn Ioan." IFI Review of the Year

Rempel, W. 1993. Delusions of a Dictator: The Mind of Marcos as Revealed in His Secret Diaries. NY: Little Brown \& Co.

Rovillos, R.D \& Tauli-Corpuz, V. (2012) "Development, Power and Identity politics in the Philippines" in Sawyer, S. \& Gomez, E.T. (eds) The Politics of Resource Extraction: Indigenous People, Multinational Corporation and the State, Basingstoke: Palgrave Macmillan. 
Rovillos, R. D., S. B. Ramo, and C. Corpuz, Jr. (2003) "When the Isles of Gold Turns into the Isle of Dissent: A Case Study on the Philippine Mining Act of 1995." Paper for the presentation at the EIR's Eminent Person and participants at the meeting on Indigenous Peoples, Extractive Industries and the World Bank," Oxford, England: Tebtebba Foundation, 1-32.

Salonga, J. 2000. Presidential Plunder: The Quest for the Marcos ill-gotten wealth. Manila: Regina Publications.

Sanders, E.J. 1963a. "Mining." American Chamber of Commerce. May, 244.

Sanders, E. J. 1963b. 'Mining.' American Chamber of Commerce. March, 135.

Santos, T. \& Mary Zaratan. 1997. "Mineral Resources Accounting: A technique for monitoring the Philippine mining industry for sustainable development." Journal of Asian Earth Sciences, 15(2-3):155-160.

Schurman, Jacob and others. 1900. "Report of the Philippine Commission to the President: January, 1(4)." United States. Philippine Commission (1899-1900).

Seagrave, S. 1988. Marcos Dynasty. New York: Harpercollins.

Slater, D. 2010. Ordering Power: Contentious Politics and Authoritarian Leviathans in Southeast Asia. Cambridge, New York: Cambridge University Press.

Smith, Warren. 1921. "Mineral Resources and Mining in the Philippines." The American Chamber of Commerce Journal. July, 34.

Stangley, P. 1974 A Nation in the Making. New Haven: Harvard University Press.

Tiglao, R. 1988. "The Consolidation of the Dictatorship" in Dictatorship and Revolution: Roots of People's Power. Manila: Conspectus.

TVI Pacific, Inc. 2013. "TVI Affiliates Secures US\$23 Million Low Interest Financing for Development of Its Balabag Gold/Silver Project." News Release, TSX: TVI.

Thompson, M. 1996. The Anti-Marcos Struggle: Personalistic Rule and Democratic Transition in the Philippines. New Haven: Yale University Press.

United Press. 1937. "Industrial Metal Prices Current." American Chamber of Commerce, August, 32.

Varias, A. 1955. "Population-density and distances enhance Manila realty values." American Chamber of Commerce. May, 12.

Vivoda, V. 2008. "Assessment of the Governance Performance of the Regulatory Regime Governing Foreign Mining Investment in the Philippines," Minerals \& Energy - Raw Materials Report 23(3): 127-43.

Waring, F. \& B. Dorfman. 1937. "Current Philippine Economics." American Chamber of Commerce. June. 
Wallerstein, Immanuel. 1974.The Modern World-system: Capitalist Agriculture and the Origins of the European World-economy in the Sixteenth Centenary. Academic Press.

Whitemore, A. 2006. "The emperors new clothes: Sustainable mining?" Journal of Cleaner Production, 14: 309-314.

Vu, T. 2010a. Paths to Development in Asia: South Korea, Vietnam, China and Indonesia. Cambridge: Cambridge University Press.

Vu, T. 2010b. "Studying the State through State Formation." World Politics 62 (1): 148-175. 